\title{
The Contribution of Behavior Accounting with the Sakinah Finance Approach to the Financial Management of Islamic Families
}

\author{
Rifatul Muawanah, Diniyah Sukma, Ahmad Zuhril Kalam, Eny Latifah \\ Institut Agama Islam Tarbiyatut Tholabah \\ Jl. KH. Musthofa 40 Kranji - Paciran - Lamongan Jawa Timur \\ E-mail: rifatulmuawanah14@gmail.com,sukm4001@gmail.com, \\ m.izulkalam33@gmail.com, eni.lathifah@gmail.com
}

\begin{abstract}
Abstrak
Tujuan penelitian ini adalah untuk mengetahui perilaku akuntansi dengan pendekatan Sakinah Finance dan nilai-nilai ekonomi Islam dalam keluarga Islam. Penelitian ini menggunakan metode deskriptif kualitatif dengan menggunakan analisis data triangulasi dengan menggabungkan wawancara, observasi, dan dokumentasi. Hasil dari penelitian ini adalah keluarga Islam mampu menerapkan Behavior Accounting dengan mencatat semua transaksi keuangan dengan menerapkan nilai-nilai ekonomi Islam berupa shiddiq, amanah, fathonah, tabligh, 'iffah, qona'ah, adil, bijaksana, ikhlas, dan ketakwaan sehingga tercapai kesejahteraan dalam hidup dan mampu meningkatkan perkembangan ekonomi Islam.
\end{abstract}

\section{Kata Kunci: Perilaku Akuntansi, Keuangan Sakinah, Nilai Ekonomi Islam, Keluarga Islami.}

\begin{abstract}
The purpose of this study was to determine behavior accounting with the Sakinah Finance approach and Islamic economic values in Islamic families. This study used a qualitative descriptive method using triangulation data analysis by combining interviews, observation, and documentation. The result of this research is that Islamic families are able to apply Behavior Accounting by recording all financial transactions by applying Islamic economic values in the form of shiddiq, amanah, fathonah, tabligh, 'iffah, qona'ah, fair, wise, sincere, and piety so that prosperity is achieved in life and able to increase the development of the Islamic economy.
\end{abstract}

Keywords: Behavior Accounting, Sakinah Finance, Islamic Economic Values, Islamic Family.

\section{INTRODUCTION}

Family financial management is important in fulfilling family needs. Money management is basically the process of managing financial assets, which consists of planning and managing money in order to meet needs and achieve financial prosperity. Planning means making a plan to manage the money you have precisely according to your needs with the aim that the money can be used properly and appropriately in accordance with the income received. 


\section{The Contribution of Behavior Accounting with the Sakinah Finance Approuchto the Financial Management of Islamic Families Rifatul Muawanah, dkk}

According to Ida and Cinthia (2010) someone who has a financial management behavior tends to make a budget, save money and control spending. Family financial managers who are able to manage family finances properly will be able to meet daily needs and set aside a portion of the money to save or provide for future needs. However, not a few of the family financial managers are not able to manage family finances properly so that the family's needs cannot be fulfilled, and will cause debt in the future.

Family financial management also needs a touch of Islamic values in it such as the sakinah finance approach, with the aim of always creating happiness and there are no family problems in terms of finances because everything has been well managed using a spiritual approach.

The implementation of Islamic values that are reflected in the behavior of financial management carried out with the sakinah finance approach is expected to be able to increase the growth of the Islamic economy in Indonesia. Because the family is the most important part of economic growth in the internal life of the community, so that in practice it is carried out with Islamic economic values that have been exemplified by the Prophet and all other easy morals such as Shiddiq, tabligh, amanah, fathonah, fairness. Wise, iffah, sincere and qona'ah and taqwa will control the existence of waste and excess in the use of family finances. So it is necessary to have a scientific basis that is able to explain it all. The author is interested in the theme of the contribution of accounting behavior with the sakinah finance approach to Islamic family financial management.

\section{LITERATURE REVIEW}

\section{Behavior Accounting}

Financial behavior is behavior by a person or group in treating, managing and using existing financial resources with responsibility for the use of their money. Such as making a budget, saving money, controlling spending, investing, and paying obligations on time (Nababan and Sadalia, 2012). 
Financial behavior indicates the pattern of a person managing all financial sources with full responsibility for all flows of money that go out for the sake of meeting the necessities of life either periodically or manually.

\section{Sakinah Finance}

Sakinah comes from the word "taskunu" which is taken from the word "sakana" which is silence, calm after being shaky and busy before. Sakinah can also be interpreted as a state of calm which is the main characteristic of family life. Meanwhile, Finance is anything or activities related to money. Money is a legal means of payment. The function of money is to accumulate wealth and also as a precautionary tool (Massasy in Rhodiyah, 2012: 20).

\section{Islamic Values in Sakinah Finance}

\section{Shiddiq}

Honesty closly related to shiddiq, because the meaning of shiddiq itself in language is true or honest. Honesty is the attitude of a person that reflects the conformity between the statement conveyed and the action or reality that occurs (Srijanti, Purwanto, and Pramono, 2007: 89). In other literature, shiddiq contains the meaning of beliefs, words and actions based on the value of truth according to Islamic law (Hafidhuddin, 2003: 36).

Honesty is a moral aspect that needs to be upheld in social and household life. A person's honest attitude can also determine a person's credibility and integrity in managing a job. A job that is handled by someone who is smart, skilled, and intellectually stable is still not enough if it is not balanced with established moral aspects, in this case honesty. If the value of honesty is not applied in the world of work or in the household, the potential for damage is greater than constructive. Honesty that is applied in the household environment can provide positive energy and has the potential to build a better household life. Likewise, lying in the household environment is believed to be a disease that injures household harmony. Regarding honesty, there are the following indicators: objective, what it is, according to reality, open, and rational (Astuti: 2000, 58).

\section{Tabligh}




\section{The Contribution of Behavior Accounting with the \\ Sakinah Finance Approuchto the Financial \\ Management of Islamic Families \\ Rifatul Muawanah, dkk}

Tabligh means being able to convey something to others through good communication. Therefore, in conveying something to others, communication skills are needed, transparency in delivery, quality substance delivered, and being able to communicate persuasively, argumentatively, and effectively (Alma and Priansa, 2009: 58). In the context of management science, tabligh is defined as delegation of authority, coordination, teamwork, control and supervision, task description, being sociable, and responsive (Hafidhuddin and Tanjung, 2008: 56). There are at least ten times the word tabligh is mentioned in the Koran, where the word tabligh is meant to convey something (revelation) through certain symbols with the aim of influencing others (Tasmara, 2001: 223). The word tabligh is also interpreted on the basis of being communicative, transparent, cultured, visionary, consistent, guiding, compassion and selfcontrol (Ryandono, 2008: 129).

Trust

Trust in language is trustworthiness, loyalty, and sincerity. As for the meaning of the term mandate is the nature of loyalty, sincerity, and responsibility for a job given to him by others (Kartajaya, Herman, and Sula, 2006: 125). In another definition, it is explained that the mandate is a valuable deposit given by God to humans so that the deposit is done properly and correctly (Srijanti, Purwanto, and Pramono, 2007: 103).

\section{Fathonah}

Fathonah is closely related to intelligence and intelligence. Fathonah can be interpreted as clever, because people who are fathonah have the ability to analyze conditions, adapt to conditions, and quickly find solutions to problems. Fathonah is also defined as intelligent, because people who have this characteristic have rapid development of thinking (intellectual), emotional, and spiritual (Tasmara, 2001: 212). In Hafidhuddin, 2003: 74, it is explained that what is meant by fathonah is to understand, understand, and appreciate everything deeply.

\section{Qona'ah}


Qona'ah in the Arabic-Indonesian dictionary is defined as "accepting what is given to him" (Maftuh, tt .: 179). According to the language qona'ah is willing / pleased, while according to the term it means accepting when you are in the absence / not having what you want (Abdullah, tth. 60). Meanwhile, according to al-Azis defines qona'ah as an attitude of pleasure with the least gift of Allah (Saifullah al-Azis in Saladin, 2013: 61) More fully explained Hamka, at least qona'ah can be interpreted into several things, including (1) willingly accept what who are there, (2) ask God for an appropriate addition and keep trying, (3) patiently accepting God's provisions, (4) putting their trust in God, (5) not being attracted by the world's deception (Hamka: 1970, 200). This component is in line with what al-Ghazali stated. That human consistency to remain self-sufficient (qona'ah) is an ability to control oneself when seeing the temptations of lust. Therefore, breaking the passions is the first step of qona'ah. On the other hand, the inability of oneself to maintain the lust, by always feeling dissatisfied without limiting what they have, of course their existence will be increasingly confused and fall into greed. (Al-Ghazali: 1990, 288). As in the hadith narrated by Jabir bin Abdullah Rasulullah SAW. Said "Abstain from being greedy, because being greedy is essentially poverty, and avoid making excuses for being greedy (ma ya'tadziru minh). (HR. Ath-Thabrani).

In other words, feeling sufficient for what belongs to him can also be identified with simplicity or adequacy in treating the material. Matter (physical) for humans, in the Islamic concept, is an element that is in line with and in harmony with immaterial (spiritual). Qona'ah is one of the good qualities, even though humans have bad qualities which are also part of every human being. However, with the potential of the human mind is able to sort and identify good qualities as a dominant part of himself or his soul and try to control his bad character. So that the good qualities that are shown in their behavior represent the state of the soul. Therefore, every individual who understands his physical and spiritual balance in carrying out any job realizes that work is an obligation, because living people have to work. This is what Hamka meant as the main meaning of the meaning of qona'ah (Hamka, 1970: 176).

'Iffah 


\section{The Contribution of Behavior Accounting with the Sakinah Finance Approuchto the Financial Management of Islamic Families Rifatul Muawanah, dkk}

The origin of the word 'iffah refers to the basic Arabic words 'affa, ya'iffu, ' iffah which means to avoid or purify oneself from bad deeds. Regarding the meaning of the term, Al-Ghazali said that 'iffah is lust that is educated by the education of reason and sharia (Sholihin, 2000: 108). Along with this understanding, Ilyas argues that 'iffah is guarding oneself from things that can degrade, drop, and destroy his self-esteem (Ilyas, 2006: 103). What needs to be emphasized in this sense is that the value of 'iffah is not sufficient for a person to abstain from actions that are prohibited by Islamic law alone, but as much as possible it is necessary to avoid actions that if they are permissible, but are not pretty to do.

Fair

Fairness is one of the qualities that humans must possess in order to uphold the truth to anyone without exception, even though it will harm themselves. Etymologically the meaning of "just" ( $a l$-'adl) means impartial, not taking sides or equating something with another (al-musawah). Another term for al-'adl is al-qist, al-misl which means equal parts. The definition of fair in terms of terminology is to equate something with another, both in terms of value and size so that something is not partial and does not differ from one another (Anonymous, 1996: 25). Meanwhile, according to Majid Khadduri (1999: 8) states that the word fair means: (1) straightening or sitting straight, amending or changing, (2) running away, departing or avoiding a wrong path to a more correct path, (3) equal or equal or equalize, and (4) balance or offset, are proportional or are in a state of balance. Fair is a quality that puts everything in a proportional place or in the middle. Fairness itself is often put equal to virtue and piety, even God has ordered to be fair in everyday life, both in the family, community, and state. Islam itself defines fair by "not wrongful and not wronged". With the various meanings of fairness above, broadly speaking it can be defined as a situation in which there are similarities in every aspect of life and no party is disadvantaged.

Wise 
The word wise in Greek uses the word sophrona from the root word sophon which means wise, careful, guarding oneself, pure simple (Barclay M. Newman, 2015: 168). According to Stenberg, wisdom is an assessment of an individual's understanding of his or her problems and involves solutions as alternative solutions to problems that maximize various kinds of balance between oneself (interpersonal), other people (intrapersonal) and various aspects of their life (extrapersonal) (Stenberg \& Jordan, 2005: 196). In another sense, it is stated that wisdom is a process by which individuals have maturity to integrate cognitive, reflective, and effective dimensions. The process by which the dynamics between the three dimensions support each other in harmony which is finally reflected in attitudes and behavior in facing all kinds of problems in life (Ardelt, 2003: 277). From the above understanding, broadly speaking it can be said that wise here is not only talking about being wise in making decisions but wise here also emphasizes self-control.

Sincere

According to Tamami (2011), in his book entitled Psychology of Sufism, it is explained that the word sincere comes from Arabic which reads akhlasa which means clean, straight and holy. Etymologically, sincerity is purity that is not mixed with the goal. In Sufi teachings, sincerity is what is needed to get closer to God in terms of intention and action (Tamami, 2011: 201). The meaning of sincere according to Imam Qusyairi means to have the intention of making Allah SWT, the only worshiper (al-Qusyairi, 1990: 183). Shaykh ibn Atha'illah explained that sincere is to do charity solely aimed at Allah as the substance that has the servant, and indeed in this case it is known by various levels, according to the taufiq given by Allah to his servant (Atha'illah, 2012: 14). Taqwa

According to al-Razy taqwa in the Qur'an means khasyyah (fear). As in the words of Allah QS. an- Nisa verse 1: بأيها الناس اتقوا رَبَّكُع "O people, fear your Lord". In addition to the meaning of fear, al-Razy revealed five other meanings of piety, namely First: faith, in accordance with the word of God which means "And remember when your Lord called to Moses: come to the wrongdoer, the people of Pharaoh, why they do not fear (QS Al-Syu'ara: 10-11). The meaning of the word taqwa in the verse is why they do not believe. Second: repentance, in 


\section{The Contribution of Behavior Accounting with the Sakinah Finance Approuchto the Financial Management of Islamic Families \\ Rifatul Muawanah, dkk}

accordance with the word of God which means: "If the people of the lands believe and are pious, We will surely bless them from the heavens and the earth, but they deny (Our verses), then We will punish them for their deeds" ( QS AlA'raf: 96). The meaning of the word taqwa in the verse is to believe and repent. Third: obedience, in accordance with the word of God which means: "And to Him belongs all that is in the heavens and the earth, and for Him (obedience) in that religion forever. So why do you fear other than God?" (Q.S. Al-Nahl: 52). The meaning of the word taqwa in the verse is why do you obey other than Allah?. Fourth: abandoning disobedience, in accordance with the word of Allah which means: "And enter the houses from the doors and fear Allah that you may prosper" (QS Al-Baqarah: 189). The meaning of the word taqwa in the verse is do not violates His rules. Fifth: sincere, in accordance with the word of God which means: "Thus (God's command). And whoever glorifies the signs of Allah, then indeed it arises from the piety of the heart "(Q.S. Al-Haj: 32). The meaning of the word taqwa in the verse is sincerity of heart.

\section{Islamic Financial Management}

Sunandar (2013) states that Muslim family financial management is very important in helping to create a harmonious household and able to support Islamic activities and daily Islamic household activities.

In fiqh, the husband must bear the family economy. If the wife earns, then the income can be used for herself and if it is used to support the family, it is worth shadaqah.

Good household financial management always maintains a balance (tawazun) between the amount of family income and the amount of expenditure. Islam teaches to always be qona'ah when the family income is not so large and tries to optimize expenditure items well. According to Imam AlGhazali, the expenditure items in a household are ZIS (Zakat, Infaq, Shadaqah), pay debts, save savings, then routine shopping. Imam Ghazali put household spending in the last order because according to him the size of an expense depends on personal habits and desires. ZIS deals with the world and the 
hereafter if not fulfilled it will bring misery in the world and the hereafter. Likewise with debt, so that if the debt is paid late, the person concerned will pay a fine and be terrorized by the debt collector. If you die, you still leave a debt that has not been resolved, it will be the responsibility of your family or offspring to pay it off. This will burden the heirs or the families left behind. If the debt is not repaid by the family or is not allowed by the creditor, it will result in losses in the hereafter. Therefore, according to Al-Ghazali, the priority of household expenditure allocation consists of at least 4 main posts, namely:

1. For zakat (minimum 2.5\% should be above 5\%)

2. Debt issuance (maximum 2.5\%)

3. Savings / investment and protection / insurance (minimum 20\%)

4. Allocation of current needs / monthly routine expenses (maximum 5\%)

\section{METHODS}

This research uses a qualitative approach with the type of case study research. Triangulation technique that combines observation, interviews, and documentation is used as a data mining technique in this study. Researchers applied descriptive analysis techniques in this study, namely describing field data as it is, then analyzed with relevant theories in order to provide accurate research results.

This study analyzes the financial behavior patterns of housewives in the North coastal areas of Gresik and Lamongan. Data was collected randomly and conducted unstructured interviews with mothers as managers of household finances. This research is based on the following proposition, household financial management managed by women as housewives and businesswomen with good religious knowledge and good managerial skills will be able to manage household finances well so as to achieve economic stability and implement an approach sharia.

\section{DISCUSSION}

In this discussion section, the author discusses the results of the field findings which are analyzed with relevant theory. The theory used by 


\section{The Contribution of Behavior Accounting with the Sakinah Finance Approuchto the Financial Management of Islamic Families Rifatul Muawanah, dkk}

researchers in analyzing behavior accounting by family financial managers is Islamic values in Islamic finance and Islamic financial management.

Based on the results of observations, interviews, and documentation, household financial management is not always played by housewives. 5 families out of 100 families studied by researchers in the Gresik and Lamongan areas indicated that the head of the household in this case is the main role in managing household finances.

Most of the household financial managers spend around 2 to 4 million rupiah per month. However, they are able to apply Islamic values in sakinah finance to the financial management of Islamic families. This can be shown from their behavior accounting who always plans a monthly expenditure and expenditure budget, prepares funds for unexpected needs, sets aside funds for savings, always monitors household account balances and expenses. Such behavior reflects the value of fathonah, because they are able to manage finances in a planned and well-measured manner. Including the value of sakinah finance related to their financial behavior is the value of 'iffah. As family financial managers, they are able to guard themselves from spending their family income lavishly without setting aside their funds for savings. Their financial behavior is also closely related to the value of wisdom in financial management. Their wisdom can determine the appropriate family financial allocation for present and future needs with consideration of the benefit for the family.

The family financial managers also record financial transactions that are used for their daily needs. The records carried out by financial managers in this case indicate that in managing their finances they also try to apply the value of shiddiq. The urgency is clear, that financial recording requires the application of shiddiq values, because family financial managers must be able to provide and submit financial reports as they are and accountably so as not to cause misuse of family funds which has the potential to create a disharmonious family atmosphere. 
The qona'ah value that exists in family financial managers is also reflected in their sufficient income to meet their daily needs. The nature of qona'ah itself is characterized by simplicity or adequacy in treating the material and optimizing expenses well even though the family income is not so large.

Regarding the values of trust, fairness, 'iffah and taqwa, of the various family financial managers, most of them have applied these values of fairness,' iffah, and taqwa in the management of family finances. In practice, the family financial managers always pay debts if they have debts. They think that debt is a responsibility that must be paid. So if they do not pay it means they have done unfairly, because it can injure the right of the creditor and this action will be rewarded by Allah SWT. Later. However, if they are able to pay their debts, it means that they are able to reflect the values of trust, 'iffah, and taqwa.

Furthermore, the wise value has also been applied by most family financial managers. This is shown from the results of interviews with family financial managers, which they tend not to use family finances for things that are not so important, such as following trends in clothing. They prefer to use family finances for more important purposes.

Of the many family financial managers in the North coastal areas of Gresik and Lamongan, they are also able to implement Islamic family financial management. This can be shown from the behavior of financial managers who tend to set aside a portion of their income in the savings and investment accounts. This also reflects the value of tabligh in the financial management of Islamic families in the coastal Pantura. Tabligh itself is marked by the ability of a family accountant to coordinate with family members regarding family financial planning, so that the use of family finances can be right on target according to planning. The value of tabligh implemented by financial managers can also be realized through deliberation activities to discuss family financial management with other family members. In addition, the family financial manager in the Pantura area is also not reluctant to practice alms as part of Islamic family financial management. This is indicated by the number or average of a family accountant who has made a budget for alms. Thus the value of sincerity in sakinah finance can be reflected through the charity they do. 


\section{The Contribution of Behavior Accounting with the Sakinah Finance Approuchto the Financial Management of Islamic Families Rifatul Muawanah, dkk}

\section{CONCLUSION}

Based on the results of the research, most Islamic family financial managers are able to apply Behavior Accounting by recording all financial transactions by applying Islamic economic values in the form of shiddiq, amanah, fathonah, tabligh, 'iffah, qona'ah, fair, wise, sincere, and taqwa, so that contribution Behavior accounting with the sakinah finance approach to Islamic family management can achieve prosperity in life and can improve the development of the Islamic economy.

Islamic family financial managers are able to implement Islamic financial management by allocating family income to the main posts in family financial expenditures, namely: (1) zakat, infaq and alms, (2) debt expenditure, (3) savings and investment, (4) allocation current needs and monthly routine expenses.

\section{REFERENCES}

Alma, Buchari., And Priansa, Donni June. 2009. Sharia Business Management. Bandung: Alfabeta.

Anonymous. 1996. Encyclopedia of Islamic Law. Jakarta: PT Ichtiar Baru Van Hoeve.

Astuti. 2000. Character Education. Bandung: Alfabeta.

Bina, Ahda. 2013. 4 Characteristics of the Prophet: Sidik-Fathanah-AmanahTablig. Surakarta: Sajada Publisher.

Ilyas, Yunahar. 2006. Akhlaq Lecture. Yogyakarta: LPPI.

Kartajaya., Herman., And Sula, Muhammad Syakir. 2006. Sharia Marketing. Bandung: Mizan Media Utama.

Manan, Abdul. 2017. Islamic Law Reform in Indonesia. Depok: Golden.

Newman, Barclay M. 2015. Greek-Indonesian Dictionary for the New Testament. Jakarta: Gunung Mulia.

Sholihin, M. 2000. Purification of the Soul in the Perspective of Al-Ghazali. Bandung: CV. Faithful Library. 
Srijanti., Purwanto s.k., and Pramono, Wahyudi. 2007. Ethics to Build a Modern Islamic Society. Yogyakarta: Graha Science.

Stenberg \& Jordan. 2005. A Handbook of Wisdom: Psychological Perspective. New York: Cambridge University Press.

Syamsuri. 2007. Islamic Religious Education. Jakarta: Erlangga.

Hafidhuddin, Didin. 2003. Islam Applicative. Jakarta: Gema Insani.

Hafidhuddin, Didin., And Tanjung, Hendri. 2008. Sharia Management in Practice. Depok: Echo of Insani.

Tamami HAG. 2011. Psychology of Sufism. Bandung: Faithful Library.

Tasmara, Toto. 2001. Spiritual Intelligence (Transedental Intelligence). Jakarta: Gema Insani.

Tuaeleka, Hamzah et al. 2011. Sufism Morals. Surabaya: IAIN Sunan Ampel Press.

Ryandono, Muhammad Nafik. 2008. Stock Exchange and Sharia Investment. Surabaya: Amanah Pustaka. 